\title{
PENGELOLAAN DANA DAN LIKUIDITAS BANK ${ }^{1}$
}

\author{
Gantiah Wuryandani \\ Ramlan Ginting \\ Dudy Iskandar \\ Zulkarnain Sitompul ${ }^{2}$
}

\begin{abstract}
This paper analyzes the liquidity of banks, both precautionary and involuntary liquidity. We apply dynamic panel estimation on individual bank data covering the period of Januari 2002 to November 2011. The result shows that precautionary liquidity is more determined by the operation of the bank. On the other hand, the involuntary liquidity is more affected by the financial system condition. Related to the size, the effect of the financial system condition and the macroeconomy is larger for the small banks. Moreover, the monetary policy in the form minimum reserve requirement affects the precautionary liquidity of the small banks; while the central bank rate is less influential to the bank liquidity.
\end{abstract}

Keywords: Banking, Liquidity, General Method of Moment

JEL classification: G21, G11, C33

1 Authors thank to Vimala Dewi, Anggayasti Hayu, Indri Tryana, and Rizka Rosdiana for their great help on data and estimation. We also thank to Dr. Telisa Aulia for their great discussion.

2 Authors are researcher on Center for Central Banking Research and Education - Bank Indonesia; gantiah@bi.go.id, ramlan_ginting@ bi.go.id, diskandar@bi.go.id, zsitompul@bi.go.id. 


\section{PENDAHULUAN}

Bank merupakan lembaga keuangan perantara (intermediary) yang dapat menghimpun dan mengalokasikan dana dari atau kepada masyarakat. Kinerja individual bank maupun sistem perbankan secara keseluruhan sangat ditentukan oleh perilaku bank dalam mengelola asset (penempatan dana) dan liabilitas (penghimpunan dana). Pengelolaan asset dan liabilitas bertujuan memperoleh keuntungan dan meningkatkan nilai perusahaan dalam batasan tertentu. Batasan tersebut mencakup tingkat likuiditas yang mencukupi, risiko yang rendah, dan modal yang mencukupi. Dengan demikian, pengelolaan asset dan liabilitas memiliki keterkaitan yang erat dengan likuiditas bank. Berdasarkan Keynes (1936), terdapat tiga motivasi dalam memegang kas atau likuiditas yaitu dalam rangka transaksi, berjaga-jaga (precautionary), dan spekulasi. Selain itu, berdasarkan pandangan Edgeworth (1888) dengan prinsip square root of law of precautionary reserves, cadangan likuiditas bank akan meningkat setara dengan akar dari jumlah transaksi.

Likuiditas bersifat rentan dan dapat secara tiba-tiba terkuras dari suatu bank. Kesulitan likuiditas pada suatu bank dapat menjalar pada bank lain sehingga menimbulkan risiko sistemik. Kejutan (shock) dapat mendorong terciptanya spiral likuiditas yang menyebabkan hilangnya likuiditas dan terbentuknya krisis keuangan. Belajar dari historis, krisis perbankan yang terjadi selama ini terutama disebabkan oleh krisis likuiditas bank yang menyebabkan terjadinya gagal bayar bank terhadap sebagian besar kewajibannya. Dalam kerangka jaring pengaman sistem keuangan (JPSK), sebagaimana juga dicetuskan oleh Bagehot (1873), bank sentral sebagai lender of the last resort (LLR) memberikan pinjaman likuiditas sementara dengan persyaratan tertentu untuk menjaga stabilitas sistem perbankan. Bantuan likuiditas diberikan terutama bila kegagalan suatu bank diperkirakan dapat menyebabkan efek menular (contagion effect) dan menimbulkan risiko sistemik. Goodhart (1987) menyatakan bahwa tidak terdapat perbedaan yang jelas antara kondisi bank yang tidak likuid dan bangkrut, dimana bank yang membutuhkan likuiditas melalui LLR pada dasarnya dapat dicurigai dalam proses menjadi bangkrut.

Cadangan likuiditas suatu bank pada umumnya merupakan jaminan atau tindakan berjaga-jaga atas kemungkinan terjadinya kewajiban membayar akibat peningkatan penarikan dana maupun peningkatan giro wajib minimum (GWM). Beberapa bank memilih melakukan strategi untuk memiliki likuiditas yang berlebih sebagai sinyal kepada pasar bahwa bank tersebut memiliki likuiditas yang kuat. Di lain sisi, kelebihan likuiditas dapat juga diinterpretasikan bahwa bank memiliki pengelolaan likuiditas yang buruk sehingga tidak optimal dalam mengelola portofolio asset dan liabilitas.

Kelebihan likuiditas dapat juga merupakan akibat dari lemahnya infrastruktur dalam sistem pembayaran dan pasar uang antar bank. Di Giorgio (1999) beranggapan bahwa perkembangan sistem keuangan dapat dicerminkan oleh biaya partisipasi dalam sistem keuangan. Di negara maju, biaya untuk memproses informasi, evaluasi proyek dan monitoring atas peminjam dana relatif rendah. Perkembangan ini memudahkan bank dalam mengelola likuiditas mereka 
sehingga tingkat cadangan likuiditas relatif rendah. Sebaliknya, negara yang memiliki sistem pembayaran yang buruk, maupun infrastruktur pasar uang antar bank yang terbatas cenderung mempersulit bank dalam mengelola likuiditas, sehingga bank cenderung memegang likuiditas yang lebih tinggi dari kebutuhannya.

Secara mikro bank, pengelolaan asset dan liabilitas bank menyangkut aspek risiko likuiditas, risiko pasar, risiko trading, penghimpunan dana dan modal, target keuntungan, dan rencana pertumbuhan. Bank secara umum menghadapi risiko yang terbagi dalam 3 kelompok yaitu risiko kredit (transaksi, counterparty, konsentrasi, dan setelmen), risiko pasar (suku bunga, nilai tukar, likuiditas), risiko operasional (proses, infrastruktur system, sumber daya manusia). Fokus utama dalam pengelolaan asset dan liabilitas bank pada umumnya adalah pengelolaan risiko likuiditas, nilai tukar, dan suku bunga. Dalam hal ini, likuiditas yang optimal adalah likuiditas yang mampu menciptakan pendapatan optimal dan mencegah terjadinya risiko likuiditas. Secara makro, bagi bank sentral pengelolaan asset dan liabilitas bank yang optimal adalah yang dapat menciptakan kondisi likuiditas sesuai dengan target kebijakan moneter.

Perilaku pengelolaan asset dan liabilitas perbankan di Indonesia saat ini mengindikasikan adanya likuiditas yang cukup banyak (surplus liquidity) ${ }^{3}$. Kelebihan ini diserap oleh bank sentral melalui kebijakan moneter dengan pendekatan pasar atau non pasar. Pendekatan pasar dilakukan melalui operasi moneter yang melibatkan transaksi antara bank sentral dengan bankbank yang bertujuan untuk menarik atau melonggarkan likuiditas di pasar, melalui transaksi surat berharga pemerintah ataupun Surat Berharga Bank Indonesia. Di Indonesia, kebijakan moneter yang dilakukan cenderung bersifat kontraktif dengan target penyerapan likuiditas berlebih yang ada di perbankan. Kondisi ini diantaranya sebagai konsekuensi kebijakan bail out pada krisis keuangan tahun 1998 dalam mengatasi bank run sistem perbankan. Pendekatan kebijakan moneter non pasar dilakukan antara lain melalui aturan kewajiban giro wajib minimum (GWM) bank untuk menempatkan dananya di bank sentral.

Ganley (2004) menyatakan bahwa surplus likuiditas dapat menimbulkan permasalahan bagi bank sentral terkait dengan mekanisme transmisi kebijakan moneter, pelaksanaan intervensi bank sentral di pasar uang, dan neraca maupun rugi/laba bank sentral. Distorsi efektivitas kebijakan moneter tersebut cenderung menimbulkan permasalahan sustainabilitas kondisi keuangan bank sentral, khususnya bila digunakan instrumen kebijakan moneter dalam bentuk surat berharga bank sentral.

Sumber utama likuiditas perbankan adalah melalui arus modal masuk (capital inflows) seperti penanaman modal asing berjangka panjang, portofolio investasi berjangka pendek, dan pembiayaan defisit fiskal. Dengan kondisi rezim devisa bebas, arus modal masuk ke Indonesia baik bersifat jangka panjang maupun spekulatif merupakan faktor yang signifikan

3 (Ganley, 2004), surplus liquidity terjadi pada saat arus kas (cash flow) di pasar melebihi kebutuhan untuk cadangan (reserves). Berdasarkan keseimbangan pasar, kondisi ini merupakan ketidakseimbangan exante dengan kecenderungan yang persisten disebabkan oleh peningkatan likuiditas otonomous di bank sentral. 
mempengaruhi likuiditas nasional. Arus modal masuk yang bersifat spekulatif lebih merupakan distorsi dalam stabilitas sistem keuangan dan moneter. Di lain sisi, arus modal masuk yang bersifat jangka panjang lebih merupakan faktor yang dapat mendukung pertumbuhan ekonomi dan perluasan kesempatan kerja.

Paper ini akan menganalisa pengaruh perilaku perbankan dalam penghimpunan dan penempatan dana terhadap kondisi likuiditas mereka. Lebih jauh, paper ini akan mengidentifikasi determinan yang mempengaruhi likuiditas bank, dan menganalisis keterkaitan kebijakan moneter dengan perilaku pengelolaan likuiditas bank.

Bagian dua dari paper ini menjelaskan teori dan studi literatur yang terkait dengan manajemen likuiditas perbankan. Bagian tiga mengulas data dan metodologi yang digunakan, sementara hasil dan analisis dijelaskan pada bagian keempat. Kesimpulan disajikan pada bagian akhir dan menjadi penutup paper ini.

\section{TEORI}

\subsection{Faktor yang Mempengaruhi Likuiditas Bank}

Dari sisi mikro perusahaan, Bank for International Settlement (2008) mendefinisikan likuiditas sebagai kemampuan bank untuk mendanai peningkatan asset dan memenuhi kewajibannya tanpa menimbulkan kerugian. Valla, Escorbiac dan Tiesset (2006) dan Vodova (2011) mendefinisikan likuiditas bank sebagai kemampuan untuk memenuhi kewajiban kas yang dapat dibedakan dalam likuiditas pendanaan (funding liquidity) dan likuiditas pasar (market liqudity) ${ }^{4}$. Borio $(1997,2001)$ berargumen bahwa perlu dibedakan antara keseimbangan likuiditas ex ante sebelum intervensi bank sentral dan ex post setelah intervensi bank sentral. Edlin dan Jaffee (2009) menyatakan bahwa tingginya likuiditas perbankan dapat disebabkan karena adanya credit crunch atau keengganan bank untuk menyalurkan kredit.

Perkembangan dan kondisi likuiditas perbankan selain dipengaruhi oleh kegiatan usaha bank juga dipengaruhi oleh sistem dalam pasar uang. Melalui pasar uang yang tersedia, bank dapat melakukan pengelolaan likuiditas baik dalam kondisi kekurangan maupun kelebihan likuiditas. Pasar uang di suatu negara ditentukan oleh struktur pasar, instrumen yang tersedia, perkembangannya, regulasi, dan kondisi likuiditas pasar. Kondisi likuiditas sistem keuangan akan menentukan kebijakan moneter yang akan dilakukan bank sentral terkait dengan target pencapaian inflasi dan menjaga momentum pertumbuhan yang berkelanjutan.

Pasar uang antar bank (PUAB) atau disebut juga interbank call money market merupakan tempat terjadinya transaksi pinjam meminjam dana antara bank dengan bank lain untuk memenuhi kebutuhan likuiditas maupun menempatkan likuiditas jangka pendek karena gap

4 Funding liquidity (Valla, Escorbiac, Tiesset,2006) adalah asset yang siap diubah menjadi kas untuk memenuhi penarikan kewajiban atau untuk kegiatan operasional. Sedangkan market liquidity didefinisikan sebagai kegiatan bank dalam perdagangan aset yang ditunjukkan oleh kemampuan bank untuk menjual asset yang bersifat non likuid. 
likuiditas harian. PUAB tidak memiliki tempat khusus dalam melakukan transaksi melainkan dilaksanakan melalui sarana over the counter (OTC), dengan komunikasi langsung antara bank peminjam dan bank pemberi pinjaman melalui RDMS (reuter dealing monitoring system). Pasar uang antar bank di Indonesia memiliki struktur pasar yang cenderung oligopoli dan tersegmentasi serta sangat dangkal. Kondisi ini membuat bank kurang fleksibel dalam memperoleh maupun mengalokasikan likuiditas secara optimal. Sebagian bank-bank besar cenderung mengalami kelebihan likuiditas dan lebih sering menjadi pemberi pinjaman (lender). Segmentasi pasar dalam PUAB seolah-olah membentuk sub sistem pasar uang sendiri di dalamnya. Dalam hal ini, bank-bank pemberi pinjaman dan bank-bank penerima pinjaman tertentu masuk dalam satu kelompok tertentu yang sering melakukan transaksi dengan pihak-pihak yang sama secara terus menerus. Kondisi ini mendorong terjadinya tingkat risiko counterparty yang berbeda dan bervariasi antar segmen termasuk disparitas harga. Dalam kondisi likuiditas ketat, PUAB cenderung terjadi segmentasi yang semakin kuat dengan meningkatnya risiko counterparty. Kondisi ini cenderung mendorong tingkat bunga PUAB yang meningkat dan disparitas harga yang lebar. Dalam hal ini, motivasi bank untuk tidak melepas likuiditas menjadi semakin tinggi dalam rangka menjaga kecukupan likuiditas.

Struktur pasar uang Indonesia memiliki instrumen yang sangat terbatas dengan instrumen surat berharga jangka pendek tidak lebih dari satu tahun seperti, commercial paper, sertifikat Bank Indonesia, repurchase agreement, banker's acceptance, dan sertifikat deposito. Masih dangkalnya instrumen dalam PUAB mendorong bank untuk mengelola likuiditas jangka pendek dengan memegang variasi instrumen yang terbatas. Pada umumnya perbankan cenderung memiliki instrumen yang bersifat sangat likuid dengan risiko rendah seperti surat berharga pemerintah (sovereign), surat berharga bank sentral, dan surat berharga jangka pendek lainnya. Selain kondisi pasar, berbagai regulasi terkait dengan manajemen risiko dan likuiditas ikut mendorong bank untuk berperilaku tertentu dalam mengelola likuiditas maupun portfolio asset dan liabilitas.

Pasar uang merupakan outlet atau sarana bank paling utama dalam mengelola likuiditas maupun pemenuhan likuiditas sehingga kondisi likuiditas perbankan secara langsung akan tercermin pada kondisi pasar uang baik dalam volume transaksi maupun tingkat bunga. Likuiditas yang ketat di perbankan ditandai dengan meningkatnya suku bunga PUAB dan spread yang semakin melebar antara harga beli dan jual. Tingkat harga di PUAB tercermin dalam harga pinjaman (borrowing) maupun harga pembiayaan (lending) dengan harga indikatif transaksi antar bank tercermin pada JIBOR (Jakarta Interbank Offered Rate), yang merupakan harga ratarata kuotasi penawaran dari bank kontributor. JIBOR tersebut dipublikasikan melalui reuters dan bloomberg serta dilaporkan oleh bank setiap hari kepada bank sentral melalui laporan harian bank umum (LHBU). Selain JIBOR, harga rata-rata dari seluruh bank dapat termonitor melalui LHBU di website bank sentral.

Di Indonesia, seluruh bank umum merupakan peserta (market player) PUAB dengan kesenjangan dalam tingkat asset dan modal yang cukup lebar. Di akhir tahun 2011, modal 
bank berkisar dari Rp0,15 triliun - Rp54 triliun, sedangkan asset bank berkisar Rp0,17 - Rp465 triliun. Bank besar dengan asset diatas Rp100 triliun hanya terdiri dari 7 bank, sedangkan bank dengan asset dibawah Rp1 triliun mencapai 20 bank, dari total 122 bank.

Hasil penelitian Vodova (2011) menunjukkan bahwa likuiditas bank di Czech yang diukur melalui beberapa indikator ditentukan secara positif oleh CAR (capital adequacy ratio), suku bunga kredit, NPL (non performing loan), dan suku bunga antar bank (PUAB). Di lain sisi, krisis keuangan, inflasi, dan pertumbuhan ekonomi memiliki dampak negatif terhadap likuiditas bank. Pengangguran, margin suku bunga, profitabilitas, dan suku bunga moneter tidak signifikan mempengaruhi likuiditas bank. Likuiditas dalam penelitian ini diukur dengan menggunakan alternatif beberapa rasio. Likuiditas rasio 1 merupakan rasio aset likuid yang siap dijual (kas, giro di bank sentral) terhadap total aset, liabilitas yang bertahan di bank, dan credit line dengan bank counterparty lain.

Shen, Chen, Kao, dan Yeh (2009) melakukan studi untuk mengetahui faktor-faktor dari risiko likuiditas dengan menggunakan data panel dari 12 negara. Hasil studi tersebut menunjukkan bahwa risiko likuiditas dipengaruhi oleh aset likuid, pembiayaan eksternal, pengawasan, regulasi, dan makro ekonomi. Risiko likuiditas berkorelasi negatif dengan kinerja bank di negara yang memiliki sistem keuangan berdasarkan market-based. Di lain sisi, di negara yang memiliki sistem keuangan berdasarkan bank-based, risiko likuiditas justru tidak berkaitan dengan kinerja bank.

Saxegaard (2006) menyatakan alasan bank untuk memegang likuiditas berlebih dari kebutuhan berjaga-jaga karena perekonomian dalam keadaan liquidity trap. Dalam kondisi ini imbal hasil kredit terlalu rendah dibandingkan dengan biaya intermediasi, dimana imbal hasil dari dana yang ditempatkan di bank sentral lebih baik dari pada memberikan kredit. Hasil studi oleh Agénor Aizenman, and Hoffmaister (2000) mengindikasikan bahwa kontraksi pada pembiayaan kredit di Thailand setelah terjadinya krisis, lebih disebabkan oleh fenomena pasokan (supply) sehingga terjadi ekses likuiditas involuntary.

Penelitian oleh Bathaludin dkk et al (2012) menyatakan bahwa perilaku bank di Indonesia menyimpan ekses likuiditas dipengaruhi oleh fluktuasi kebutuhan uang kartal, pertumbuhan ekonomi, biaya dana, dan lag likuiditas secara signifikan. Likuiditas precautionary dalam penelitian tersebut didefinisikan sebagai rasio dana bank yang ditempatkan dalam surat berharga bank sentral (ekses likuiditas) terhadap dana pihak ketiga. Sedangkan likuiditas involuntary diperoleh dari residual hasil estimasi likuiditas precautionary. Pontes dan Sol Murta (2012) menemukan bahwa likuiditas berlebih terjadi karena lemahnya perkembangan sektor keuangan dimana PUAB kurang efisien, diversifikasi instrumen keuangan yang rendah, dan lemahnya intermediasi kredit karena dianggap memilki biaya yang mahal.

Total likuiditas yang dipegang bank secara sistem keseluruhan tidak berubah walaupun terjadi perubahan rasio pada level individual bank. Namun, perubahan pada level bank tersebut mempengaruhi komposisi likuiditas yang dibutuhkan akibat adanya ekses likuiditas. Berdasarkan 
penelitian yang dilakukan Keister dan McAndrew (2009), jumlah likuiditas yang ada di bank ditentukan oleh tindakan bank sentral dan tidak mencerminkan perilaku pembiayaan bank. Di lain sisi, Ganley (2004) berpendapat bahwa beberapa faktor yang menentukan likuiditas bank diantaranya berada diluar kendali bank sentral, seperti arus pembayaran ke dan dari giro bank di bank sentral atau jumlah uang yang dipegang masyarakat.

Aspachs, Nier, dan Tiesset (2005) melakukan penelitian pada likuiditas bank di UK menggunakan data kuartalan individual bank dari tahun 1985-2003. Hasil penelitian tersebut menunjukkan bahwa semakin besar dukungan bank sentral pada saat krisis likuiditas, semakin rendah cadangan likuiditas yang dipegang bank. Sebagian besar bank di UK juga cenderung melakukan counter cyclical likuiditas dengan mencadangkan likuiditas yang rendah pada saat ekonomi tumbuh. Asset likuid dalam penelitian ini terdiri dari kas, reverse repo, dan commercial paper. Variabel dependen merupakan rasio likuiditas yaitu rasio antara aset likuid dengan total aset, atau rasio antara aset likuid dengan total deposit. Variabel penjelas (expalanatory variable) terdiri dari NIM, profit, pertumbuhan kredit, size, pertumbuhan produk domestik bruto (PDB), dan suku bunga jangka pendek. Suku bunga dan PDB memiliki pengaruh yang kuat terhadap likuiditas, demikian pula kesempatan untuk melakukan pembiayaan ke depan.

Di lain sisi, penelitian oleh Acharya dan Merrouche (2010) terhadap permintaan likuiditas dan setelmen bank-bank di UK serta efeknya terhadap PUAB pada saat sebelum dan sesudah krisis sub-prime menunjukkan bahwa bank di UK memegang likuiditas lebih tinggi 30 persen setelah PUAB dihentikan pada tanggal 9 Agustus 2007 sebagai sifat dasar untuk berjagajaga (precautionary). Kondisi ini menciptakan likuiditas ketat sehingga menimbulkan krisis. Meningkatnya permintaan likuiditas oleh bank dalam rangka setelmen mendorong suku bunga ON meningkat dan menimbulkan potensi risiko sistemik.

Kebijakan untuk meredam stress dan fluktuasi suku bunga pada pasar antar bank harus dilakukan antara lain melalui pengawasan, stress test dini, rekapitalisasi pada bank bermasalah, serta pencadangan likuiditas melebihi cadangan likuiditas darurat. Hasil penelitian Berger dan Bouwman (2009) menunjukkan bahwa kebijakan moneter tidak memberikan efek yang signifikan terhadap pembentukan likuiditas pada bank besar dan menengah yang memiliki pangsa likuiditas sekitar 90\%. Kebijakan moneter justru efektif mempengaruhi likuiditas pada bank kecil. Selain itu, tidak terdapat perbedaan yang signifikan antara dampak kebijakan moneter pada saat krisis keuangan dan pada saat normal.

Henry, Birchwood, dan Primus (2010) melakukan studi untuk mengestimasi permintaan atas precautionary reserve dan dampak dinamika involuntary reserve terhadap kebijakan moneter di Trinidad dan Tobago, dengan menggunakan GMM (generalized method moment) dan VAR (vector autoregression). Hasil studi menunjukkan bahwa bank melakukan excess reserve dalam rangka berjaga-jaga terhadap kekurangan likuiditas. Spread antara suku bunga kredit dan dan suku bunga bank sentral mempengaruhi precautionary reserves secara negatif. Selain itu, dinamika involuntary reserves dipengaruhi terutama oleh operasi fiskal. Demikian pula 
penurunan kredit dalam masa pertumbuhan ekonomi yang menurun cenderung memperbesar likuiditas bank.

Penelitian lain yang dilakukan oleh Pontes dan Sol Murta (2010) dengan menggunakan TSLS (two stage least square) menunjukkan bahwa perkembangan kredit, surat berharga pemerintah dan krisis mempengaruhi keputusan likuiditas bank. Tingginya suku bunga kredit menyebabkan terhambatnya intermediasi bank sehingga likuiditas menumpuk.

\subsection{Peran Kebijakan Moneter terhadap Likuiditas Perbankan}

Kebijakan moneter dilakukan bank sentral dalam rangka menjaga stabilitas moneter guna mengendalikan likuiditas nasional. Melalui pengendalian likuiditas nasional diharapkan pelaksanaan pembangunan ekonomi dapat berkelanjutan. Di Indonesia, bank sentral menetapkan suku bunga kebijakan yang disebut BI rate. Suku bunga tersebut diharapkan merupakan acuan (reference rate) bagi pelaku pasar dalam melakukan kegiatan ekonomi. Instrumen kebijakan moneter saat ini terdiri dari surat berharga Bank Indonesia, standing facility Bank Indonesia, dan giro wajib minimum (GWM). Penggunaan surat berharga Bank Indonesia dilakukan melalui operasi pasar terbuka (open market operation), terdiri dari sertifikat Bank Indonesia (SBI) dan term deposit.

Jangka waktu SBI semula 1 bulan kemudian diperpanjang menjadi 6 bulan di tahun 2011 . Term deposit merupakan lelang surat berharga Bank Sentral yang lebih panjang mencapai 9 bulan. Di lain sisi, standing facility Bank Indonesia yang ditetapkan sejak Juni 2008 merupakan fine tune operation dalam rangka mengendalikan suku bunga overnight (ON) pasar uang antar bank (PUAB) agar bergerak disekitar suku bunga BI rate (interest rate corridor), dengan harapan transmisi kebijakan moneter melalui jalur suku bunga dapat berjalan.

Standing facility terdiri dari fasilitas penempatan dan pinjaman dengan suku bunga berdasarkan pada suku bunga BI rate ditambah/dikurangi spread tertentu. Dalam hal bank mengalami kelebihan likuiditas, bank dapat menempatkan kelebihan dana di Bank Indonesia dengan menggunakan suku bunga penempatan fasilitas Bank Indonesia (deposit facility). Sebaliknya dalam hal bank mengalami kesulitan likuiditas, bank dapat memperoleh dana pinjaman dari Bank Indonesia (lending facility) dengan menggunakan suku bunga pinjaman fasilitas Bank Indonesia. Interest rate corridor tersebut pada awalnya menggunakan spread simetris dari pergerakan BI rate. Di akhir tahun 2012 spread antara suku bunga fasilitas penempatan terhadap BI rate adalah sebesar -175 basis poin, sementara spread fasilitas pinjaman terhadap $\mathrm{BI}$ rate adalah sebesar +100 basis poin.

Di lain sisi, kebijakan moneter non pasar melalui instrumen giro wajib minimum (GWM) yaitu kewajiban perbankan untuk menempatkan dananya di Bank Indonesia berdasarkan persentase tertentu terhadap dana pihak ketiga yang dihimpun. Kebijakan GWM terkini dikaitkan dengan kewajiban pemenuhan loan to deposit ratio (LDR) dalam rangka meningkatkan 
utilitas optimal likuiditas perbankan melalui peningkatan fungsi intermediasi guna mendukung pertumbuhan ekonomi. Dalam hal ini bank diwajibkan memenuhi LDR berkisar 78-100\%. Di luar batasan tersebut, bank dikenakan penalti tambahan kewajiban GWM tertentu. Bank sentral memberikan jasa giro bagi bank dengan batasan maksimum 3\% dari dana pihak ketiga (DPK). Besar imbalan yang disediakan Bank Indonesia adalah sebesar BI rate dikurangi 2,5\% sehingga dana tersebut tidak membebani perbankan karena hilangnya time value of money.

Pengelolaan asset dan liabilitas bank diibaratkan sebagai jantung yang menjaga tetap beroperasinya suatu bank. Implikasi dari pengelolaan asset dan liabilitas adalah kondisi likuiditas bank yang dapat mempengaruhi risiko sistemik, transmisi dan kebijakan moneter. Dengan demikian, pengelolaan asset dan liabilitas memiliki keterkaitan yang sangat erat dengan likuiditas bank. Ketidakpastian penarikan dana dari sisi liabilitas mendorong strategi pengelolaan asset yang mampu memenuhi kewajiban suatu bank. Selain itu, perubahan dan volatilitas suku bunga, nilai tukar ikut menentukan pemenuhan kondisi yang mampu mendanai penarikan kewajiban secara tiba-tiba maupun secara masif dan serentak.

Freixas, Martin, dan Skeie (2009) melakukan penelitian efisiensi pasar uang antar bank dalam alokasi dana dan kebijakan bank sentral yang optimal dalam menghadapi kejutan likuiditas. Hasil penelitian menunjukkan bahwa pada saat terjadi distributional liquidity shock crisis yang menimbulkan segmentasi likuiditas di pasar (disparitas) antara bank yang berbeda, bank sentral seharusnya menurunkan suku bunga antar bank. Kegagalan untuk menurunkan suku bunga pada saat krisis, justru akan memperburuk stabilitas keuangan dengan meningkatnya probabilitas terjadinya bank run (penarikan dana secara serentak oleh depositor).

Dari sisi kepentingan makro, Saxegaard (2006) menyatakan perlu dibedakan antara ekses likuiditas untuk berjaga-jaga (precautionary) dengan ekses likuiditas yang melebihi kebutuhan untuk berjaga-jaga (involuntary). Di negara sub-sahara Afrika (SSA), bank cenderung memiliki ekses likuiditas yang bersifat involuntary karena kurang berkembangnya pasar uang, alokasi kredit yang kurang, dan meningkatnya simpanan pemerintah di bank. Jika bank memiliki ekses likuiditas yang tinggi untuk memenuhi kebutuhan berjaga-jaga (precautionary), maka sterilisasi melalui kebijakan moneter tidak perlu dilakukan karena tidak berpotensi menciptakan inflasi.

Perilaku perbankan di negara SSA di atas dapat mengindikasikan adanya masalah struktural sehingga alokasi dana menjadi tidak efisien. Likuditas involuntary pada umumnya sebagai secondary reserve dan ditujukan untuk mengatasi kemungkinan terjadinya liquidity gap dalam operasional atau kemungkinan terjadinya gejolak likuiditas. Dengan memegang likuiditas yang bersifat involuntary berarti bank juga kehilangan kesempatan untuk memperoleh pendapatan tertentu. Dalam hal ini, Sacerdoti (2005) berpendapat di negara-negara SSA diperlukan pengembangan informasi debitur, standar akuntansi dan auditing, hukum dan kerangka peraturan. O'Connell (2005) juga berpendapat bahwa ekses likuiditas yang bersifat involuntary juga akan mengganggu mekanisme transmisi kebijakan moneter. Dengan demikian, pemahaman terhadap sumber-sumber ekses likuiditas menjadi hal yang penting untuk mampu menetapkan kebijakan moneter yang tepat. 
Saxegaard (2006) melakukan studi pola ekses likuiditas bank-bank di negara-negara sub sahara Afrika dengan menggunakan SVAR (structural vector autoregression). Hasil penelitian menunjukkan bahwa ekses likuiditas bank melemahkan mekanisme transmisi kebijakan moneter, sehingga otoritas moneter tidak dapat mengendalikan permintaan di perekonomian. Hampir senada dengan Saxegaard, Ganley (2004) juga menyatakan bahwa operasi penyerapan likuiditas oleh otoritas cenderung menggunakan alat instrumen moneter yang lemah seperti surat berharga bank sentral dengan suku bunga yang tinggi, sehingga kurang efektif dalam transmisi kebijakan moneter. Dalam jangka panjang, hal ini menimbulkan implikasi penting terhadap keuangan bank sentral dengan meningkatnya biaya operasi moneter. Kondisi ini dapat secara serius mempengaruhi pendapatan bank sentral dan independensinya dari pemerintah. Jika terjadi kerugian bank sentral secara terus menerus, maka dibutuhkan rekapitalisasi dari pemerintah.

Meltzer (2009) maupun Feldstein (2009) berpendapat bahwa meningkatnya likuiditas bank dapat menimbulkan tekanan inflasi dengan penciptaan uang yang cepat melalui kredit sehingga bank sentral harus menyerap kelebihan likuditas. Namun demikian, Keister dan McAndrews (2009) menyatakan kondisi tersebut terjadi bila menggunakan kerangka operasi moneter tradisional. Saat ini Federal Reserve memberikan imbalan bunga pada likuiditas bank yang disimpan di bank sentral sehingga dapat meningkatkan suku bunga pasar dan menahan laju pertumbuhan kredit tanpa mengubah jumlah likuditas. Dengan memberikan bunga untuk cadangan bank yang ditempatkan pada bank sentral, maka bank sentral dapat mengatur suku bunga jangka pendek yang independen terhadap tingkat likuiditas sehingga dapat menghambat tekanan inflasi. Dengan kata lain, likuiditas berlebih di bank tidak selalu menimbulkan tekanan inflasi. Studi oleh Bathaluddin, Adhi, dan Wahyu (2012) dengan menggunakan TVAR (threshold vector autoregression) mengindikasikan bahwa telah terjadi switching regime dari likuiditas rendah kepada likuiditas tinggi di Indonesia pada tahun 2005. Selain itu, ekses likuiditas menyebabkan kebijakan moneter dalam mengendalikan inflasi menjadi tidak efektif.

Berger dan Bouwman (2009) dalam penelitiannya menunjukkan bahwa kebijakan moneter menimbulkan efek penciptaan likuiditas secara signifikan hanya pada bank kecil. Namun tidak terdapat perbedaan yang signifikan atas dampak kebijakan moneter terhadap penciptaan likuiditas pada saat normal atau krisis.

\section{METODOLOGI}

Kerangka pikir dari penelitian ini secara umum sebagaimana pada diagram di bawah ini. Kegiatan usaha bank dalam penghimpunan dan penempatan dana mempengaruhi kondisi likuiditas bank. Pada sisi lain, kondisi likuiditas bank akan mempengaruhi aktifitas perekonomian yang tercermin dari pergerakan PDB (produk domestik bruto), dan selanjutnya ini akan mempengaruhi inflasi. Tingkat inflasi yang terjadi dan ekspektasi inflasi ke depan akan menentukan reaksi kebijakan moneter yang akan dilakukan bank sentral dalam mengendalikan 
likuiditas nasional guna mencapai tujuan menjaga tingkat inflasi. Kebijakan tersebut akan mempengaruhi kondisi makroekonomi seperti pergerakan suku bunga dan nilai tukar, maupun pertumbuhan ekonomi. Perkembangan ini selanjutnya akan mempengaruhi kebijakan bank dalam melakukan penghimpunan dan penempatan dana. Penghimpunan dana bank dapat berbentuk giro, tabungan, deposito, pinjaman, maupun modal. Di lain pihak, penempatan dana dapat berbentuk kas, giro di bank sentral, giro di bank lain, surat berharga, kredit, dan penempatan lain. Kondisi ini akan menciptakan siklus yang saling berkaitan satu sama lain.

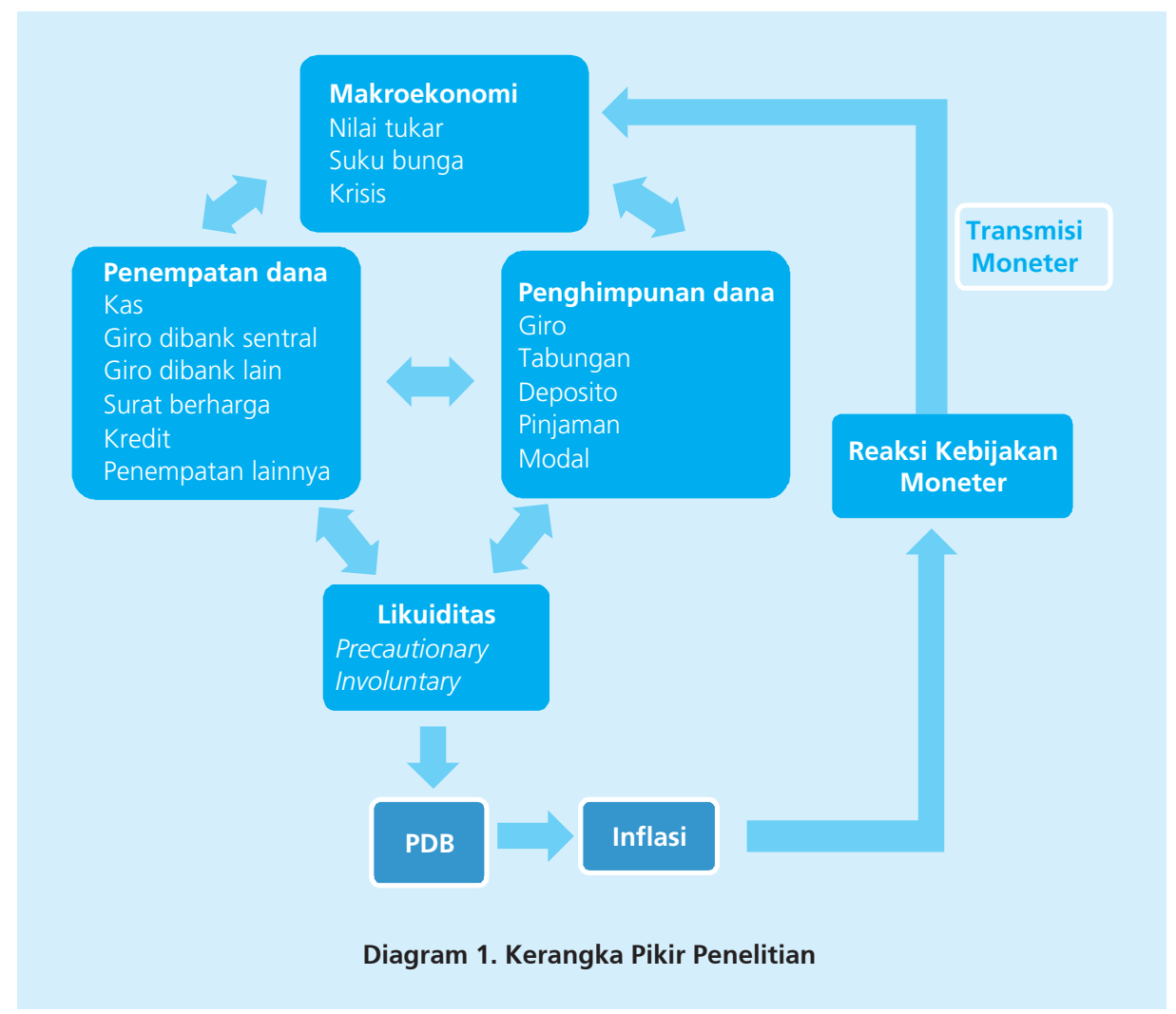

Data yang digunakan dalam penelitian ini adalah logaritma data bulanan longitudinal/ panel individual bank dari bulan Januari 2002 sampai dengan November 2011 dari publikasi laporan keuangan bank. Sampel observasi bank yang digunakan adalah 110 bank dari total populasi 122 bank. Dalam studi ini, sampel bank hanya bank konvensional dan tidak termasuk bank syariah, menimbang bank syariah memiliki mekanisme kegiatan operasional dan pasar uang yang berbeda. Pembagian klasifikasi bank dalam pengujian dilakukan berdasarkan batasan asset, bank besar (big bank) dengan asset diatas Rp50 triliun, bank menengah (medium bank) diatas Rp10 triliun, dan bank kecil (small bank) dibawah Rp10 triliun. 
Bank terkecil memiliki asset diatas Rp100 miliar karena adanya ketentuan batasan minimal modal Rp100 miliar sejak tahun 2010. Pemilihan jumlah bank dan periode waktu untuk memenuhi persyaratan bahwa dimensi observasi cross section lebih besar dari dimensi series waktu ( $\mathrm{N}>\mathrm{T}$ ) dan untuk mengontrol heterogenitas individu bila terdapat perilaku yang unobservable.

Metodologi yang akan digunakan dalam penelitian ini adalah regresi panel data dinamis dengan generalized method moment (GMM). Pemilihan penggunaan model GMM berdasarkan pada kerangka panel data model sebagaimana diagram dibawah.

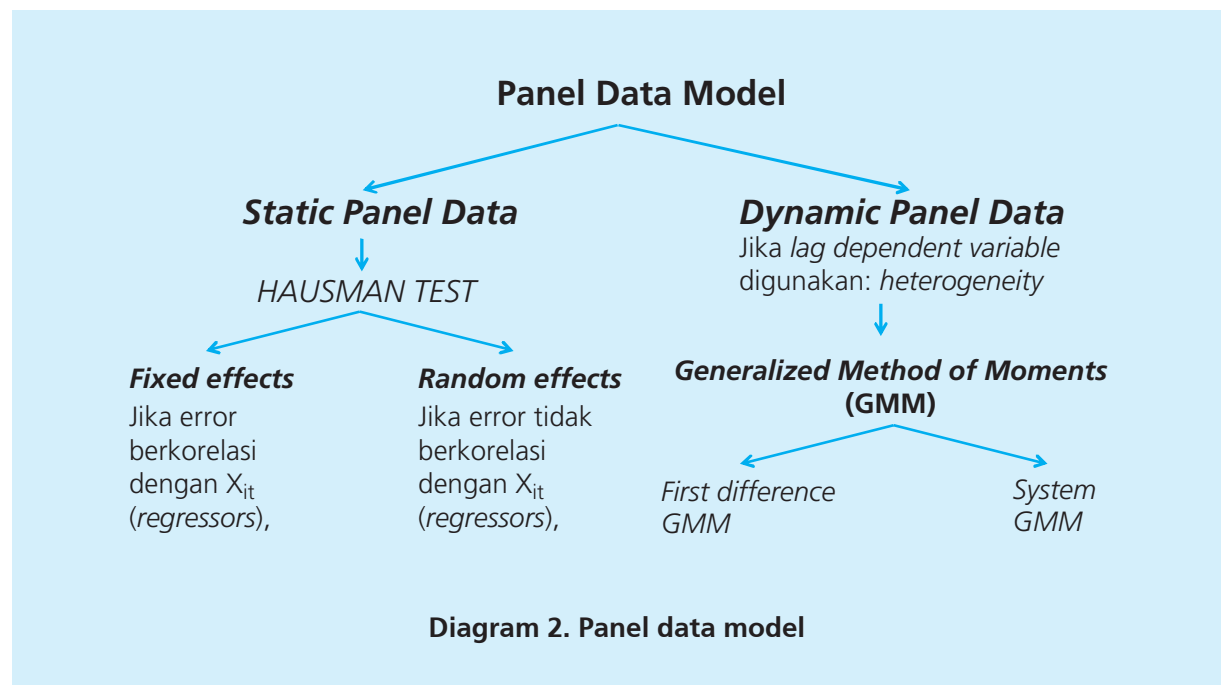

Spesifikasi model empiris untuk panel data dinamis adalah sebagai berikut:

$$
Y_{i t}=\alpha Y_{i, t-1}+\beta X_{i t}+\mu_{i t}
$$

Dimana $Y_{i t}$ adalah variabel dependen (endogenous), $\alpha$ adalah koefisien parameter variabel lag endogen, $X_{i t}$ adalah explanatory variables (exogenous), $\beta$ adalah koefisien parameter $X_{i t}$ dan $\bigcup_{i t}$ adalah residual. Variabel instrumen (IV) yang digunakan adalah lag tertentu dari variabel endogen dan eksogen yang tidak berkorelasi dengan shock pada saat t. Secara umum simbol dan deskripsi variabel yang digunakan sebagaimana pada Tabel 1 Lampiran A.

Variabel endogen yang diuji dibedakan dalam bentuk likuiditas dalam rangka precautionary dan involuntary, mendekati pendefinisian oleh Saxegaard (2006), Valla dkk.

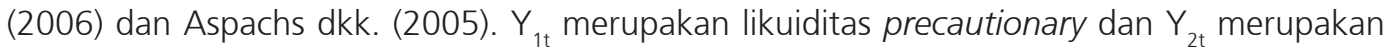
likuiditas involuntary. Likuiditas precautionary $\left(Y_{1 \mathrm{t}}\right)$ sebagaimana persamaan (2) merupakan rasio dari gabungan kas (CASH), kewajiban giro wajib minimum/reserve requirement (RR) 
dan penempatan giro pada BI, serta giro pada bank lain (ODD) dibandingkan total asset (TA). Dalam hal ini likuiditas precautionary lebih ditentukan oleh kebutuhan dalam rangka kegiatan operasional fundamental.

Setiap bank memiliki kebutuhan likuiditas yang berbeda-beda tergantung pada kegiatan operasional dan segmen pasarnya, serta risiko yang dapat ditoleransi. Berdasarkan focus group discussion, beberapa bank menganggap minimal harus tersedia likuiditas precautionary sekitar 2-10\%. Batasan (threshold) rasio asset likuid terhadap total asset setiap bank berbeda-beda tergantung kegiatan operasional usaha, kebutuhan likuiditas yang bersifat historis (historical) dan selera risiko. Likuiditas involuntary $Y_{2 t}$ sebagaimana persamaan (3) merupakan rasio antara gabungan surat berharga yang siap dijual dalam bentuk sekuritas di bank sentral (CBSEC), penanaman dalam surat berharga pemerintah (GSEC) dan surat berharga lain (OSEC) dibandingkan dengan total asset (TA). Penempatan sekuritas di Bank Sentral dapat berbentuk sertifikat Bank Indonesia, term deposit, dan standing facility Bank Indonesia. Sebagian bank beranggapan rasio asset likuid involuntary berkisar 15-18\% sudah merupakan batasan waspada (alert).

$$
\begin{aligned}
& Y_{1 t}=\frac{C+R R+O D D}{T A_{i, t}} \\
& Y_{2 t}=\frac{C B S E C+G S E C+O S E C}{T A_{i, t}}
\end{aligned}
$$

Pemilihan variabel penjelas (explanatory variable) terhadap likuiditas precautionary dan involuntary didasarkan pada komponen neraca sebagai respresentasi dari penghimpunan dan penempatan dana, kebijakan moneter, kondisi sistem keuangan dan ekonomi makro. Variabel yang dianggap mempengaruhi likuiditas precautionary lebih diarahkan pada variabel yang sangat terkait dengan kegiatan usaha bank, karena likuiditas tersebut memiliki sifat berjagajaga. Di lain sisi, variabel likuiditas involuntary lebih kearah kondisi pasar dan sistem keuangan, maupun makro ekonomi. Persamaan GMM likuiditas precautionary $\left(Y_{1 t}\right)$ adalah sebagaimana pada persamaan berikut.

$$
\begin{aligned}
& Y_{1 i, t}=\alpha Y_{1 i, t-1}+\beta_{1} \operatorname{RRRATE}_{t}+\beta_{2} D T_{i, t}+\beta_{3} \operatorname{CREDIT}_{i, t}+\beta_{4} \mathrm{FSI}_{t}+\beta_{5} O N_{t}+\varepsilon_{i, t} \\
& D T_{i, t}=\frac{D D_{i, t}+S_{i, t}+T D_{i, t}}{T A_{i, t}} \\
& \operatorname{CREDIT}_{i, t}=\frac{\text { CRED }_{i, t}}{T A_{i, t}}
\end{aligned}
$$


dimana $\mathrm{i}=1, \ldots ., \mathrm{N}$ adalah sampling observasi bank sejumlah 110 dan $\mathrm{t}=1$. ...t adalah dimensi waktu dalam bulanan dari bulan Januari 2002 sampai dengan November 2011 mencapai 119 dimensi waktu. $Y_{1 \mathrm{i}, \mathrm{t}-1}$ adalah lag dari variabel endogen likuiditas precautionary, RRRATE ${ }_{. t}$ adalah tingkat giro wajib minimum (reserve requirement), DT $\mathrm{T}_{\mathrm{i}, \mathrm{t}}$ sebagaimana persamaan (5) adalah rasio dana pihak ketiga yang terdiri dari total giro $\left(\mathrm{DD}_{\mathrm{i}, \mathrm{t}}\right)$, tabungan $\left(\mathrm{S}_{\mathrm{i}, \mathrm{t}}\right)$, dan deposito $\left(\mathrm{TD}_{\mathrm{i}, \mathrm{t}}\right)$ terhadap total asset $\left(\mathrm{TA}_{\mathrm{i}, \mathrm{t}}\right)$, CREDIT $\mathrm{i}_{\mathrm{t}, \mathrm{t}}$ sebagaimana persamaan (6) adalah rasio kredit $\left(\mathrm{CRED}_{\mathrm{i}, \mathrm{t}}\right)$ terhadap total asset $\left(\mathrm{TA}_{\mathrm{i}, \mathrm{t}}\right.$ ). $\mathrm{FSI}_{\mathrm{t}}$ adalah financial stability index yang merupakan indikasi tekanan terhadap stabilitas sistem keuangan dalam bentuk komposit indeks sistem perbankan dan pasar modal, $\mathrm{ON}_{\mathrm{t}}$ adalah suku bunga overnight pasar uang antar bank, dan $\varepsilon_{\mathrm{i}, \mathrm{t}}$ adalah error term dari persamaan precautionary.

Persamaan GMM likuiditas involuntary $\left(Y_{2 t}\right)$ adalah sebagaimana pada persamaan berikut.

$$
\begin{aligned}
& Y_{2 i, t}=\alpha Y_{2 i, t-1}+\beta_{1} \text { BIRATE }_{t}+\beta_{2} \text { ER }_{t}+\beta_{3} \text { CREDIT }_{i, t}+\beta_{4} \text { FSI }_{t}+ \\
& \beta_{5} C A R_{i, t}+\beta_{6} G D P_{t}+\varepsilon_{i, t}
\end{aligned}
$$

dimana $\mathrm{i}=1, \ldots, \mathrm{N}$ adalah sampling observasi bank sejumlah 110 dan $\mathrm{t}=1$. ...t adalah dimensi waktu dalam bulanan dari bulan Januari 2002 sampai dengan November 2011. Y Yit,-1 $_{\text {adalah }}$ lag dari variabel endogen likuiditas involuntary, BIRATE ${ }_{\text {. }}$ adalah kebijakan moneter suku bunga bank sentral, ER t $_{\text {adalah pergerakan nilai tukar nominal, CREDIT }}$, adalah rasio kredit terhadap total asset sebagaimana persamaan (6), FSI adalah financial stability index, $\mathrm{CAR}_{\mathrm{i}, \mathrm{t}}$ adalah capital adequacy ratio atau persentase kewajiban pemenuhan modal minimum bank, $\mathrm{GDP}_{\mathrm{t}}$ adalah produk domestik bruto, dan $\varepsilon_{\mathrm{i}, \mathrm{t}}$ adalah error term dari persamaan involuntary.

\section{HASIL DAN ANALISIS}

\subsection{Statistik Deskriptif}

Statistik deskriptif variabel yang digunakan dalam penelitian ini dalam periode observasi dari bulan Januari 2002 sampai dengan November 2011, sebagaimana pada tabel 2. Tingginya standar deviasi likuiditas involuntary menunjukkan bahwa volatilitas likuiditas involuntary $\left(Y_{2 t}\right)$ cenderung dinamis sepanjang rentang waktu observasi sebagaimana dapat dilihat pada grafik 1. Sebaliknya, likuiditas precautionary cenderung memiliki volatilitas yang relatif stabil dibanding likuiditas involuntary, sebagaimana juga ditunjukkan oleh standar deviasi yang tidak terlalu tinggi.

Rentang pergerakan likuiditas precautionary relatif lebih rendah berkisar 500 basis point. Hal ini mengindikasikan bahwa likuiditas involuntary cenderung mengikuti pergerakan dinamis dari situasi ekonomi dengan rentang pergerakan berkisar 1.300 basis point (13\%). Pada saat krisis mini tahun 2005 dan krisis keuangan internasional tahun 2008 sebagaimana 
ditunjukkan oleh financial stability index (FSI) yang berada diatas threshold 2, likuiditas involuntary mengalami penurunan yang cukup signifikan sebagaimana digambarkan dalam grafik. Kondisi ini menunjukkan bahwa dalam hal terjadi kesulitan likuiditas di pasar, maka likuiditas involuntary digunakan sebagai cadangan utama untuk menyangga kesulitan tersebut. Bank-bank cenderung melakukan mencadangkan likuiditas yang tinggi pada masa ketahanan sistem keuangan relatif tinggi yang kemudian digunakan pada masa ketahanan sistem keuangan cenderung berubah menjadi rentan. Kondisi ini cenderung bersifat countercyclical terhadap situasi likuiditas pasar.

Di lain sisi, volatilitas nilai tukar $\left(\mathrm{ER}_{\mathrm{t}}\right.$ ) relatif stabil dan hanya terjadi lonjakan yang signifikan di tahun 2008 akhir sampai dengan pertengahan tahun 2009 pada saat terjadi krisis keuangan dunia akibat subprime mortgage di Amerika Serikat sebagaimana digambarkan dalam grafik 3. Relatif stabilnya pergerakan nilai tukar antara lain dipengaruhi juga oleh kebijakan intervensi oleh Bank Sentral. Stabilitas nilai tukar juga menjadi salah satu target bank sentral dalam menjaga stabilitas nilai Rupiah sebagaimana diamanatkan dalam Undang-Undang Bank Sentral, selain target pada inflasi.

Berdasarkan grafik 4, pergerakan BI rate tidak mempengaruhi penempatan dana bank di surat berharga bank sentral. Semakin menurunnya kebijakan moneter BI rate tidak menurunkan minat bank untuk tetap meningkatkan penempatan dananya di surat berharga bank sentral.

\subsection{Precautionary Liquidity}

Persamaan likuiditas precautionary GMM untuk seluruh bank (all bank) cukup baik dan tidak bias keatas maupun kebawah (lihat Tabel 3 dalam Appendix D). Statistik Sargan test menunjukkan bahwa validitas instrumen variabel (IV) cukup baik. Likuiditas precautionary seluruh bank secara umum dipengaruhi secara signifikan oleh lag dari likuiditas precautionary sendiri $\left(\mathrm{Y}_{1 \mathrm{i}, \mathrm{t}-1}\right)$, tingkat giro wajib minimum (RRRATE $\left.{ }_{\mathrm{t}}\right)$, dana pihak ketiga $\left(\mathrm{DT}_{\mathrm{i}, \mathrm{t}}\right)$, $\operatorname{kredit}\left(\mathrm{CREDIT}_{\mathrm{i}, \mathrm{t}}\right)$, financial stability index $\left(\mathrm{FSI} \mathrm{t}_{\mathrm{t}}\right)$, dan suku bunga PUAB $\left(\mathrm{ON}_{\mathrm{t}}\right)$.

Berdasarkan klasifikasi bank, pengujian mengindikasikan bahwa lag likuiditas precautionary paling berpengaruh terhadap likuiditas precautionary, demikian pula dana pihak ketiga (kecuali pada bank menengah), diikuti oleh kredit dan suku bunga PUAB ON. Bank masih melihat kondisi likuiditas historis dalam menetapkan likuiditas saat ini, dan ini sejalan dengan hasil penelitian Bathaluddin dkk. (2012). Positifnya dampak dana pihak ketiga terhadap likuiditas precautionary mengingat bahwa meningkatnya penghimpunan dana bank akan memberikan kesempatan yang lebih luas bagi bank untuk mengalokasikan dana termasuk dalam rangka ekspansi usaha. Kredit pada bank besar, menengah dan kecil berpengaruh secara negatif atas perkembangan likuiditas precautionary. Hal ini sejalan dengan hasil penelitian oleh Henry dkk. (2010) dan Pontes dan Sol Murta (2010). 
Kondisi pasar uang yang terefleksi pada suku bunga PUAB ON berpengaruh secara negatif atas likuiditas precautionary. Ketatnya likuiditas di pasar uang yang terindikasi pada suku bunga PUAB yang meningkat akan mengurangi likuiditas precautionary bank karena bank cenderung mengalami kesulitan dalam memperoleh likuiditas. Hasil ini sejalan dengan hasil penelitian Vodova (2011) dan Acharya dan Merrouche (2010). Di lain sisi, giro wajib minimum (GWM) dan financial stability index (FSI), tidak terlalu berpengaruh terhadap perubahan likuiditas precautionary, kecuali pada bank kecil. Hasil ini menunjukkan bahwa kebijakan moneter non pasar melalui GWM hanya berpengaruh pada bank kecil, sejalan dengan hasil penelitian Berger dan Bouwman (2009).

Bank berukuran kecil relatif memiliki kegiatan yang terbatas sehingga mencadangkan likuiditas yang relatif kecil. Ini menyebabkan perubahan GWM cenderung memiliki pengaruh yang signifikan terhadap perkembangan likuiditas bank kecil tersebut. Di lain sisi, tidak signifikannya dampak kebijakan moneter GWM terhadap bank besar dan bank menengah antara lain karena bank-bank tersebut memiliki likuiditas yang jauh lebih tinggi dan sanggup berfungsi sebagai cadangan (buffer) diatas kebutuhan likuiditas untuk kegiatan operasional. Penjelasan lain kemungkinan karena besaran GWM sampai dengan saat ini masih dalam batasbatas yang dapat dipenuhi oleh bank besar dan bank menengah secara mudah. Di samping itu, untuk dana yang ditempatkan di giro bank sentral (sejumlah maksimum 3 persen dari total dana pihak ketiga), bank sentral menyediakan imbalan suku bunga sebesar 2 pesen, dan ini lebih tinggi dibandingkan beban biaya riil yang ditanggung perbankan.

Signifikannya FSI terhadap likuiditas precautionary bank kecil menunjukkan bahwa meningkatnya FSI mengindikasikan kondisi stabilitas pasar keuangan cenderung berpotensi terganggu dan biasanya diikuti dengan ketatnya likuiditas di pasar uang, sehingga bank kecil cenderung mengurangi likuiditas precautionary untuk memenuhi kewajibannya. Kondisi ini menunjukkan bahwa ketahanan likuiditas bank kecil sangat dipengaruhi oleh kondisi sistem keuangan, termasuk juga pasar modal.

\subsection{Likuiditas Involuntary}

Persamaan likuiditas involuntary pada Tabel 4 lampiran D menunjukkan likuiditas involuntary pada seluruh bank (all bank) ditentukan oleh lag dari likuiditas involuntary sendiri $\left(\mathrm{Y}_{2, \mathrm{t}}\right)$, suku bunga kebijakan moneter $\mathrm{BI}$ rate $\left(\mathrm{BIRATE}_{\mathrm{t}}\right)$, suku bunga PUAB $\left(\mathrm{ON}_{\mathrm{t}}\right)$, nilai tukar $\left(\mathrm{ER}_{\mathrm{t}}\right)$, kredit (CREDIT $\left.\mathrm{i}_{\mathrm{i}, \mathrm{t}}\right)$, capital adequacy ratio $\left(\mathrm{CAR}_{\mathrm{i} . \mathrm{f}}\right)$, financial stability index (FSIt), dan produk domestik bruto $\left(G P_{t}\right)$. Peningkatan suku bunga PUAB, nilai tukar, dan FSI akan mengurangi likuiditas involuntary bank. Pengujian pada seluruh bank menunjukkan bahwa peningkatan BI rate cenderung kurang kuat mempengaruhi peningkatan likuiditas involuntary. Bank cenderung menggunakan likuiditas involuntary sebagai penyangga dalam menjaga likuiditas apabila terjadi perubahan di pasar keuangan maupun sistem keuangan. Perlu digarisbawahi bahwa estimasi untuk sampel bank berukuran menengah tidak menghasilkan persamaan yang baik 
meski tidak bias (upward maupun downward biased). Hal ini terindikasi dari Sargan test yang mengindikasikan variabel instrumen yang digunakan kurang valid.

Secara umum, likuiditas involuntary dipengaruhi secara signifikan oleh likuiditas involuntary periode sebelumnya. Pada sampel bank besar, likuiditas involuntary hanya signifikan dipengaruhi oleh likuiditas sebelumnya. Kuatnya pengaruh likuiditas involuntary historikal terhadap penentuan likuiditas saat ini sejalan dengan hasil penelitian Bathaluddin dkk. (2012). Pengaruh PUAB ON signifikan pada semua kelompok bank kecuali pada bank besar. Di lain sisi, pengaruh capital adequacy ratio (CAR) signifikan pada pengujian di bank kecil dan seluruh bank. Pengaruh CAR yang signifikan terhadap likuiditas involuntary juga sejalan dengan kajian Vodova (2011).

Berdasarkan pengujian seluruh bank, BI rate relatif kecil berpengaruh pada perubahan likuditas. Namun hasil pengujian ini tidak dapat dikonfirmasi oleh hasil pengujian likuiditas involuntary pada bank besar, menengah, maupun kecil. Kurang kuatnya pengaruh kebijakan suku bunga moneter (BI rate) sejalan dengan hasil penelitian Vodova (2012). Penjelasan hal tersebut kemungkinan bahwa penempatan bank dalam surat berharga Bank Sentral bukan karena insentif suku bunga BI rate. Hal ini terefleksi pada pergerakan suku bunga BI rate dan penempatan dana bank di surat berharga bank sentral yang tidak menunjukkan hubungan terbalik atas kedua variabel tersebut. Volume penempatan dana bank pada surat berharga bank sentral terus meningkat, walaupun perkembangan suku bunga $\mathrm{BI}$ rate secara umum cenderung menurun.

Selain itu, fleksibilitas surat berharga bank sentral sebagai instrumen likuiditas cenderung semakin berkurang dengan semakin panjangnya jangka waktu surat berharga tersebut. Kondisi ini kemungkinan terjadi karena bank pada dasarnya mengalami likuiditas tinggi, dimana kecepatan pemberian kredit relatif lebih lambat dibandingkan kecepatan peningkatan penghimpunan dana. Di lain sisi, penempatan dana dalam bentuk lainnya di pasar keuangan relatif masih terbatas antara lain dengan adanya beberapa aturan dalam transaksi devisa dan saham, serta belum berkembangnya instrumen di pasar uang.

Nilai tukar hanya berpengaruh pada bank menengah, sedangkan suku bunga PUAB ON hanya berpengaruh pada bank menengah dan bank kecil. Likuiditas involuntary pada bank kecil dipengaruhi oleh lag-nya sendiri, suku bunga PUAB, CAR, FSI, dan GDP. Kondisi ini menunjukkan bahwa likuiditas involuntary pada bank kecil juga sangat ditentukan oleh kondisi makroekonomi dan sistem keuangan. Kondisi ekonomi makro seperti FSI dan PDB hanya mempengaruhi likuiditas bank kecil, sejalan dengan hasil penelitian Aspachs dkk. (2005).

Pada sampel bank besar, likuiditas involuntary periode sebelumnya sangat signifikan mempengaruhi pergerakan likuiditas involuntary periode sekarang. Di lain sisi, berbagai variabel lain kurang sensitif mempengaruhi pergerakan likuiditas involuntary yang mengindikasikan bahwa bank besar memiliki likuiditas yang sangat tinggi. Ketahanan likuiditas bank besar menunjukkan kondisi yang relatif jauh lebih baik dari pada bank kecil. Bank besar dalam 
kenyataannya cenderung merupakan pemberi pinjaman di pasar uang (lender). Hal ini juga didukung oleh lebih mudahnya bank besar dalam memperoleh penghimpunan dana dengan biaya yang lebih murah dibandingkan bank kecil. Kemudahan tersebut didukung oleh faktor infrastruktur, jejaring dan produk bank yang lebih lengkap, serta kredibilitas bank besar yang dianggap lebih baik. Kerentanan bank kecil tersebut mengindikasikan bahwa perlu dilakukan merger untuk mengubah kemampuan aset bank kecil termasuk ketahanannya terhadap likuiditas.

\section{KESIMPULAN}

Likuiditas perbankan dalam kajian ini dibagi dalam dua kelompok yaitu likuiditas precautionary dan likuiditas involuntary. Likuiditas precautionary merupakan rasio gabungan antara kas, giro pada bank sentral dan bank umum terhadap asset. Sedangkan likuiditas involuntary terdiri dari rasio surat berharga yang dapat diperdagangkan baik surat berharga bank sentral, pemerintah maupun surat berharga lainnya terhadap asset.

Kajian ini menunjukkan bahwa penghimpunan dan pengelolaan dana perbankan mempengaruhi keputusan likuiditas perbankan. Variabel kebijakan moneter dan pasar keuangan seperti tingkat GWM (giro wajib minimum), suku bunga PUAB (pasar uang antar bank), dan FSI (financial stability index) lebih berpengaruh pada likuiditas precautionary bank kecil. Selain sangat kuat dipengaruhi oleh likuiditas yang lalu, likuiditas precautionary secara umum cenderung lebih dipengaruhi oleh kegiatan operasional bank.

Likuiditas involuntary cenderung lebih digunakan sebagai penyangga likuiditas operasional oleh bank. Hal ini terindikasi dari lebih berpengaruhnya situasi di pasar keuangan terhadap likuiditas involuntary. Kebijakan moneter melalui suku bunga ( $\mathrm{Bl}$ rate) hanya berpengaruh pada bank menengah, sedangkan pada bank besar dan kecil tidak menunjukkan pengaruh sama sekali. Dengan demikian, pengaruh kebijakan moneter melalui BI rate tidak terlalu kuat mempengaruhi perkembangan likuiditas involuntary bank. Hasil pengujian ini menunjukkan bahwa secara umum kebijakan moneter justru lebih berpengaruh pada likuiditas bank kecil. Sistem keuangan dan kondisi makroekonomi seperti financial stability index, dan produk domestik bruto cenderung mempengaruhi penetapan likuiditas involuntary bank kecil.

Kurang kuatnya pengaruh kebijakan moneter, mengindikasikan bahwa Bank Indonesia tidak perlu menyerap likuiditas melalui suku bunga Bank Indonesia yang tinggi, mengingat likuiditas bank lebih ditentukan oleh kondisi operasional, permodalan, kondisi sistem keuangan, dan makroekonomi.

Secara implisit, tingginya likuiditas involuntary yang dipegang bank cenderung disebabkan masih dangkalnya pasar uang di Indonesia dan tingginya ketidakpastian perolehan likuiditas di pasar. Oleh karena itu, perlu pengembangan pasar keuangan (financial deepening) guna memperluas instrumen likuditas bank di pasar keuangan yang mampu berfungsi sebagai 
penyangga likuiditas bank sekaligus memberikan fleksibilitas yang optimum bagi bank dalam pengelolaan likuiditas. Guna mendorong berkembangnya instrumen di pasar uang, ketergantungan bank terhadap bank sentral dalam menempatkan likuiditas perlu dikurangi, antara lain dengan meninjau ulang standing facility bank sentral.

Kebutuhan untuk membangun perbankan yang kuat melalui merger menjadi semakin mendesak. Kurang tahannya bank kecil terhadap situasi ekonomi makro dan sistem keuangan menunjukkan bahwa bank-bank tersebut perlu digabung untuk mampu memiliki asset yang lebih besar sehingga pengelolaan likuiditas dan kredibilitas dapat meningkat. Hal ini juga dalam rangka mempersiapkan sistem perbankan Indonesia untuk mampu bersaing di pasar internasional dengan adanya pasar terintegrasi seperti MEA (Masyarakat Ekonomi ASEAN) di 2015. 


\section{DAFTAR PUSTAKA}

Acharya, V.V, and Merrouche, O. 2010. Precautionary Hoarding of Liquidity and Inter-bank Markets: Evidence from the Sub-prime Crisis. NBER working paper No. 16395.

Agenor,P.R., Aizenman, J., and Hoffmaister, A. 2000. The credit crunch in east asia: What can bank excess liquidity tells us? National Bureau of Economic Research, Working Paper No.7951.

Alper, K., Hulagu, T., and Keles, G. 2012. An empirical study on liquidity and bank lending. Central Bank of Turkey.

Aspachs,O., Nier, E., Tiesset,M. 2005. Liquidity, Banking Regulation and the Macroeconomy. Evidence on bank liquidity holdings from a panel of UK-resident banks. Bank of England Working Paper.

Bagehot, W.1873. Lombard Street, a Description of the Money Market. Henry S. King,

Bank for International Settlement. 2008. Principles for sound liquidity risk management and supervision.

Bank for International Settlements. 2009. International framework for liquidity risk measurement, standards and monitoring.

Bathaluddin, M.B, Adhi, N.M, dan Wahyu, A.W. 2012. Dampak Persistensi Ekses Likuiditas terhadap Kebijakan Moneter. Buletin Ekonomi Moneter dan Perbankan vol 14., No. 3, Bank Indonesia.

Berger, A.N., dan Bouwman, C.H.2009. Bank liquidity creation, monetary policy, and financial crises. University of South Carolina.

Borio, C. 1997. The implementation of monetary policy in industrial countries: A survey. Bank for International Settlements, Economic Papers No. 47.

Borio, C. 2001. A hundred ways to skin a cat: Comparing monetary policy operating procedures in the United States, Japan, and Euro area. Bank for International Settlements, Monetary and Economic Department Papers No. 9.

Brunnermeier, M. K. 2009. Deciphering the Liquidity and Credit Crunch 2007-2008. Journal of Economic Perspectives, Vol. 23, No. 1, pp. 77-100.

Di Giorgio, G.1999. Financial development and reserve requirements. Journal of Banking and Finance. 
Drehmann,M. and Nikolau,K. 2009.Funding Liquidity Risk. Definition and Measurement. ECB Working Paper, No. 1024.

Edgeworth, F., 1888. The mathematical theory of banking, Journal of the Royal Statistical Society, 51, 113-127.

Edlin, A.S. and Jaffee, D. 2009. Show Me the Money. University of California, Berkeley.

Freixas,X. and Rochet, J.C. 1998. Microeconomics of Banking. Massachusetts Institute of Technology.

Freixas,X., Martin,A., dan Skeie, D. 2009. Bank Liquidity, Interbank Markets, and Monetary Policy. Federal Reserve Bank of New York Staff Reports, No. 371.

Ganley, J. 2004. Surplus Liqudity: Implications for Central Banks. Lecture Series no:3, Centre for Central Banking Studies, Bank of England.

Goodhart, C. 1987. Why Do Banks Need a CB?. Oxford Economic Papers, p 75-89.

Henry, L., Birchwood, A., and Primus, K. 2010. The dynamics of involuntary commercial banks' reserves in Trinidad and Tobago. XLII Annual Monetary Studies Conference.

Keister, T. and Mc Andrews, J. 2009. Why are banks holding so many excess reserves? Federal Reserve Bank of New York, Staff Reports.

Keynes, J.M., 1936. The General Theory of Employment, Interest and Money. McMillan,London.

London.

O'Connell, S. 2005. Note on Excess Liquidity. Working paper, International Monetary Fund.

Pontes, G. and Sol Murta, F. 2012. The determinants of the bank's excess liquidity and the credit crisis: the case of Cape Verde. Faculdade de Economia da Universidade de Coimbra.

Sacerdoti, E. 2005. Access to Bank Credit in Sub-Saharan Africa: Key Issues and Reform Strategies. Working paper, International Monetary Fund.

Saxegaard, M. 2006. Excess Liquidity and Effectiveness of Monetary Policy: Evidence from SubSaharan Africa. Working paper, International Monetary Fund.

Shen, C.H., Chen, Y.K., Kao,L.F., Yeh, C.Y. 2009. Bank Liquidity Risk and Performance.

Vodova, P. 2011. Liquidity of Czech Commercial Banks and Its Determinants. International Journals of Mathematical Models and Methods in Applied Sciences, issues 6, volume 5. 


\section{LAMPIRAN A}

\begin{tabular}{|c|c|c|c|}
\hline \multicolumn{4}{|c|}{$\begin{array}{c}\text { Tabel } 1 \\
\text { Deskripsi Variabel (Seluruh Variable Dalam Bentuk Logaritma) }\end{array}$} \\
\hline Variabel & Deskripsi & Sumber Data & Expected Sign \\
\hline \multicolumn{4}{|c|}{ Variabel Endogen } \\
\hline$Y_{1 i, t}$ & $\begin{array}{l}\text { Likuiditas Precautionary merupakan } \\
\text { merupakan rasio dari gabungan kas (CASH), } \\
\text { kewajiban giro wajib minimum/reserve } \\
\text { requirement (RR) dan penempatan giro pada } \\
\text { BI, serta giro pada bank lain (ODD) } \\
\text { dibandingkan total asset (TA). }\end{array}$ & $\begin{array}{l}\text { Publikasi Bank, Bank } \\
\text { Indonesia (Diolah) }\end{array}$ & \\
\hline$Y_{2 i, t}$ & $\begin{array}{l}\text { Likuiditas Involuntary merupakan rasio dari } \\
\text { rasio antara gabungan surat berharga yang } \\
\text { siap dijual dalam bentuk sekuritas di bank } \\
\text { sentral (CBSEC), penanaman dalam surat } \\
\text { berharga pemerintah (GSEC) dan surat } \\
\text { berharga lain (OSEC) dibandingkan dengan } \\
\text { total asset (TA) }\end{array}$ & $\begin{array}{l}\text { Publikasi Bank, Bank } \\
\text { Indonesia (Diolah) }\end{array}$ & \\
\hline \multicolumn{4}{|c|}{ Variabel Pendukung Endogen } \\
\hline C & Kas & $\begin{array}{l}\text { Publikasi Bank, Bank } \\
\text { Indonesia }\end{array}$ & \\
\hline $\mathrm{RR}$ & $\begin{array}{l}\text { Dana GWM dan dana pada giro } \\
\text { di Bank Indonesia }\end{array}$ & $\begin{array}{l}\text { Publikasi Bank, Bank } \\
\text { Indonesia }\end{array}$ & \\
\hline ODD & Giro pada bank lain & $\begin{array}{l}\text { Publikasi Bank, Bank } \\
\text { Indonesia }\end{array}$ & \\
\hline CBSEC & $\begin{array}{l}\text { Penanaman surat berharga di Bank } \\
\text { Indonesia dalam bentuk SBI, term deposit, } \\
\text { dan fasilitas Bank Indonesia }\end{array}$ & $\begin{array}{l}\text { Publikasi Bank, Bank } \\
\text { Indonesia }\end{array}$ & \\
\hline GSEC & Penanaman pada surat berharga pemerintah & $\begin{array}{l}\text { Publikasi Bank, Bank } \\
\text { Indonesia }\end{array}$ & \\
\hline OSEC & Penanaman pada surat berharga lainnya & $\begin{array}{l}\text { Publikasi Bank, Bank } \\
\text { Indonesia }\end{array}$ & \\
\hline TA & Total Aset & $\begin{array}{l}\text { Publikasi Bank, Bank } \\
\text { Indonesia }\end{array}$ & \\
\hline \multicolumn{4}{|c|}{ Variabel Eksogen } \\
\hline$Y_{1 i, t-1}$ & $\begin{array}{l}\text { Lag dari variable endogen likuiditas } \\
\text { precautionary }\end{array}$ & $\begin{array}{l}\text { Publikasi Bank, Bank } \\
\text { Indonesia (Diolah) }\end{array}$ & Positif (+) \\
\hline $\mathrm{Y}_{2 \mathrm{i}, \mathrm{t}-1}$ & $\begin{array}{l}\text { Lag dari variable endogen likuiditas } \\
\text { involuntary }\end{array}$ & $\begin{array}{l}\text { Publikasi Bank, Bank } \\
\text { Indonesia (Diolah) }\end{array}$ & Positif (+) \\
\hline RRRATE $_{. t}$ & $\begin{array}{l}\text { tingkat giro wajib minimum (reserve } \\
\text { requirement) }\end{array}$ & Bank Indonesia & Positif (+) \\
\hline $\mathrm{DT}_{\mathrm{i}, \mathrm{t}}$ & $\begin{array}{l}\text { dana pihak ketiga yang terdiri dari total } \\
\text { giro, tabungan, dan deposito }\end{array}$ & $\begin{array}{l}\text { Publikasi Bank, Bank } \\
\text { Indonesia (Diolah) }\end{array}$ & Positif (+) \\
\hline DDi,t & Giro pada liabilitas bank & $\begin{array}{l}\text { Publikasi Bank, Bank } \\
\text { Indonesia }\end{array}$ & \\
\hline $\mathrm{S}_{\mathrm{i}, \mathrm{t}}$ & Tabungan pada liabilitas bank & $\begin{array}{l}\text { Publikasi Bank, Bank } \\
\text { Indonesia }\end{array}$ & \\
\hline $\mathrm{TD}_{\mathrm{i}, \mathrm{t}}$ & Deposito berjangka & $\begin{array}{l}\text { Publikasi Bank, Bank } \\
\text { Indonesia }\end{array}$ & \\
\hline
\end{tabular}


Tabel 1

Deskripsi Variabel (Seluruh Variable Dalam Bentuk Logaritma) Lanjutan

\begin{tabular}{l|l|l|l}
$\begin{array}{l}\text { Variabel } \\
\text { Variabel Endogen }\end{array}$ & \multicolumn{1}{c|}{ Deskripsi } & Sumber Data \\
\hline CREDIT $_{\mathrm{i}, \mathrm{t}}$ & Rasio kredit terhadap total asset & $\begin{array}{l}\text { Publikasi Bank, Bank } \\
\text { Indonesia }\end{array}$ & Negatif $(-)$ \\
\hline $\mathrm{CAR}_{\mathrm{i}, \mathrm{t}}$ & capital adequacy ratio atau persentase & Publikasi Bank, Bank & Positif $(+)$ \\
\hline $\mathrm{FSI}_{\mathrm{t}}$ & $\begin{array}{l}\text { financial stability index yang merupakan } \\
\text { indikasi tekanan terhadap stabilitas sistem } \\
\text { keuangan dalam bentuk komposit index } \\
\text { sistem perbankan dan pasar modal }\end{array}$ & Bank Indonesia & Negatif $(-)$ \\
\hline $\mathrm{ON}_{\mathrm{t}}$ & suku bunga overnight pasar uang antar bank & Bank Indonesia & \\
\hline $\mathrm{BIRATE}_{. \mathrm{t}}$ & kebijakan moneter suku bunga bank sentral & Bank Indonesia & Negatif $(-)$ \\
\hline $\mathrm{ER}_{\mathrm{t}}$ & nilai tukar nominal & Bank Indonesia & Positif $(+)$ \\
\hline $\mathrm{GDP}_{\mathrm{t}}$ & pertambahan domestik bruto & Bank Indonesia & Negatif $(-)$ \\
\hline$\varepsilon_{, \mathrm{t}}$ & error term dari persamaan likuiditas & & Positif $(+)$
\end{tabular}




\section{LAMPIRAN B}

Seluruh data diperoleh dari statistik publikasi Bank Indonesia yang merupakan longitudinal/ panel data bulanan dari individual bank konvensional, kebijakan moneter, pasar uang dan valuta asing, serta data macro ekonomi dari bulan Januari 2002 sampai dengan November 2011.

\begin{tabular}{|c|c|c|c|c|c|}
\hline \multicolumn{6}{|c|}{$\begin{array}{c}\text { Tabel } 2 \\
\text { Statistik Deskriptif Variabel }\end{array}$} \\
\hline Variabel & Mean & Median & Maximum & Minimum & Std. Dev. \\
\hline \multicolumn{6}{|l|}{ Variabel Dependen } \\
\hline$Y_{1, t}$ & $-2,74$ & $-2,72$ & $-0,40$ & $-7,06$ & 0,59 \\
\hline$Y_{2 i, t}$ & $-1,99$ & $-1,84$ & 1,50 & $-14,56$ & 1,00 \\
\hline \multicolumn{6}{|c|}{ Variabel Kebijakan Moneter } \\
\hline BIRATE $_{. t}$ & 2,17 & 2,11 & 2,84 & 1,79 & 0,27 \\
\hline RRRATE $_{. t}$ & 1,78 & 1,61 & 2,35 & 1,61 & 0,26 \\
\hline \multicolumn{6}{|c|}{ Variabel Aset Liabilitas Bank } \\
\hline $\mathrm{CAR}_{\mathrm{i}, \mathrm{t}}$ & 3,16 & 3,00 & 8,61 & $-2,12$ & 0,66 \\
\hline CREDIT $_{i, t}$ & $-0,70$ & $-0,59$ & 1,19 & $-6,47$ & 0,48 \\
\hline $\mathrm{DT}_{\mathrm{i}, \mathrm{t}}$ & $-0,46$ & $-0,27$ & 1,43 & $-10,12$ & 0,67 \\
\hline \multicolumn{6}{|c|}{ Variabel Pasar Uang dan Valas } \\
\hline $\mathrm{ER}_{\mathrm{t}}$ & 9,13 & 9,12 & 9,41 & 9,02 & 0,07 \\
\hline $\mathrm{ON}_{\mathrm{t}}$ & 2,04 & 1,96 & 2,75 & 1,50 & 0,30 \\
\hline \multicolumn{6}{|l|}{ Variabel Makro Ekonomi } \\
\hline $\mathrm{FSI}_{\mathrm{t}}$ & 0,21 & 0,39 & 0,89 & $-1,77$ & 0,53 \\
\hline $\mathrm{GDP}_{\mathrm{t}}$ & 13,70 & 13,68 & 14,47 & 12,96 & 0,47 \\
\hline
\end{tabular}




\section{LAMPIRAN C}

Likuiditas precautionary $\left(\mathrm{Y}_{\mathrm{i}, \mathrm{t}}\right)$ adalah rasio antara penjumlahan kas, giro di $\mathrm{BI}$, dan giro di bank lain dengan total asset sebagaimana persamaan (2). Likuiditas involuntary $\left(\mathrm{Y}_{2 \mathrm{i}, \mathrm{f}}\right)$ merupakan rasio antara gabungan surat berharga yang siap dijual terdiri dari penempatan dana di bank sentral dalam bentuk sekuritas, penanaman dalam surat berharga pemerintah dan surat berharga lain dengan total aset sebagaimana persamaan (3). Likuiditas precautionary dan involuntary dalam grafik ini merupakan aggregate likuiditas perbankan.

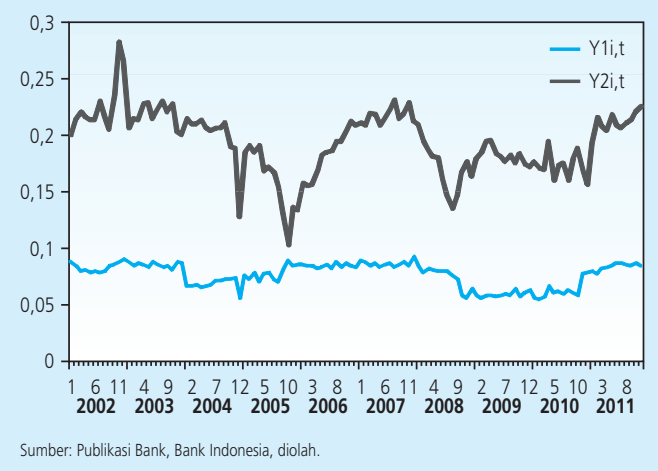

Grafik 1. Likuiditas Precautionary $\left(\mathrm{Y}_{1, \mathrm{t}}\right)$ dan Involuntary $\left(_{\text {Y2i, }}\right.$ ) 
FSI (financial stability index) adalah indeks komposit di pasar keuangan yang terdiri dari perbankan dan pasar modal untuk mengukur daya tahan sistem keuangan. Likuiditas involuntary $\left(\mathrm{Y}_{2 \mathrm{i}, \mathrm{t}}\right)$ merupakan rasio antara gabungan surat berharga yang siap dijual terdiri dari penempatan dana di bank sentral dalam bentuk sekuritas, penanaman dalam surat berharga pemerintah dan surat berharga lain dengan total aset sebagaimana persamaan (3).

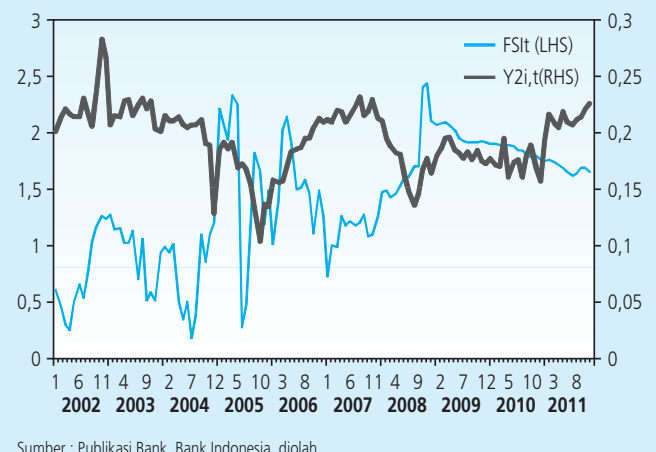

Grafik 2. FSI dan likuiditas Involuntary

BIRATEt adalah suku bunga kebijakan moneter yang ditetapkan bank sentral dalam rangka operasi pasar terbuka. ERt adalah nilai tukar nominal.

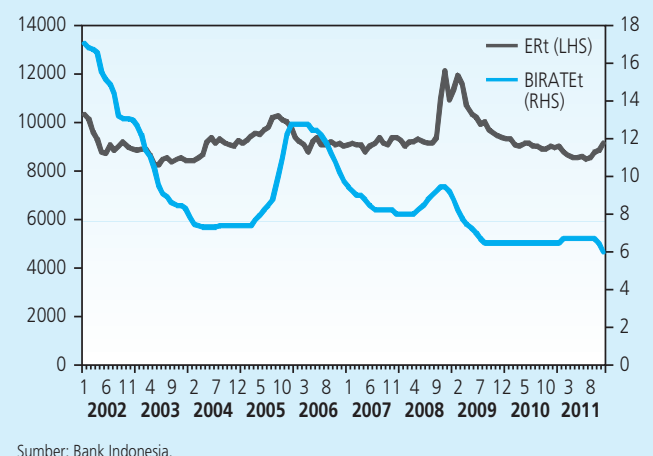

Grafik 3. BI Rate dan Nilai Tukar 
CBSEC $_{i, t}$ adalah penempatan dana bank di Bank sentral antara lain dalam bentuk term deposit, surat berharga Bank Indonesia, dan fasilitas Bank Indonesia. BIRATEt adalah suku bunga kebijakan moneter yang ditetapkan bank sentral dalam rangka operasi pasar terbuka.

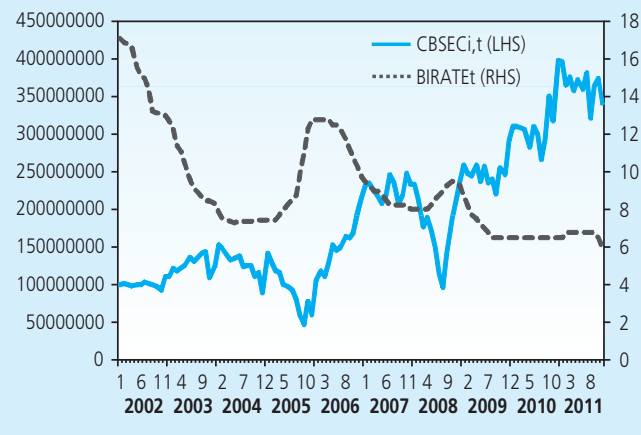

Sumber: Publikasi Bank, Bank Indonesia 


\section{LAMPIRAN D}

Tabel ini menunjukkan hasil GMM (generalized method moment) atas likuiditas precautionary (lihat Tabel 1. untuk simbol dan deskripsi variabel). Model likuiditas precautionary mengikuti persamaan (4). Instrumen variabel (IV) yang digunakan adalah lag dependen dan independen, dimana panjang lagi IV setiap model berbeda-beda untuk memperoleh hasil yang signifikan. Jumlah sampling untuk seluruh bank 110, big bank 17, medium bank 28, dan small bank 65, berdasarkan besarnya aset. Periode sampel dari Januari 2002 s.d November 2011 dengan menggunakan data bulanan longitudinal panel.

\begin{tabular}{|c|c|c|c|c|}
\hline \multicolumn{5}{|c|}{$\begin{array}{c}\text { Tabel } 3 \\
\text { Determinan likuiditas precautionary }\end{array}$} \\
\hline \multicolumn{5}{|c|}{ Dependent variable : Liquidity Precautionary $\left(\mathrm{Y}_{1 \mathrm{i}, \mathrm{t}}\right)$} \\
\hline \multirow{2}{*}{ Variable } & All bank & Big bank & Medium bank & Small bank \\
\hline & (1) & (2) & (3) & (4) \\
\hline \multirow{2}{*}{$Y_{1 \mathrm{i},-1}$} & 0,87 & 0,76 & 0,69 & 0,89 \\
\hline & $(300,7)^{*}$ & $(-5,45)^{*}$ & $(19,84)^{*}$ & $(88,53)^{*}$ \\
\hline \multirow[t]{2}{*}{ RRRATE $_{t}$} & 0,07 & $-0,34$ & 0,18 & 0,08 \\
\hline & $(25,69)^{*}$ & $(-1,36)$ & $(1,36)$ & $(16,75)^{*}$ \\
\hline \multirow[t]{2}{*}{$\mathrm{DT}_{\mathrm{i}, \mathrm{t}}$} & 0,29 & 0,36 & 0,08 & 0,14 \\
\hline & $(46,91)^{*}$ & $(-4,25)^{*}$ & $(1,27)$ & $(11,26)^{*}$ \\
\hline \multirow[t]{2}{*}{ CREDIT $_{\mathrm{i}, \mathrm{t}}$} & 0,07 & $-0,08$ & $-0,17$ & $-0,03$ \\
\hline & $(42,61)^{*}$ & $(-1,68)^{\star *}$ & $(-3,77)^{*}$ & $(-4,5)^{*}$ \\
\hline \multirow[t]{2}{*}{$\mathrm{FSI}_{\mathrm{t}}$} & $-0,03$ & 0,0007 & $-0,008$ & $-0,02$ \\
\hline & $(-222,5)^{*}$ & $(0,08)$ & $(-1,12)$ & $(-29,36)^{*}$ \\
\hline \multirow[t]{2}{*}{$\mathrm{ON}_{\mathrm{t}}$} & $-0,03$ & $-0,21$ & $-0,09$ & $-0,03$ \\
\hline & $(-43,73)^{*}$ & $(-3,75)^{*}$ & $(-1,76)^{\star *}$ & $(-22,04)^{*}$ \\
\hline J Sargan test & 109,74 & 12,57 & 24,19 & 64,28 \\
\hline ( $p$ value) & 0,49 & 0,76 & 0,67 & 0,5 \\
\hline Number of Bank & 110 & 17 & 28 & 65 \\
\hline
\end{tabular}


Tabel ini menunjukkan hasil GMM (generalized method moment) atas determinan (lihat tabel 1. untuk simbol dan deskripsi variabel) likuiditas involuntary pada persamaan (7). Definisi likuiditas involuntary sebagaimana persamaan (3). Instrumen variabel (IV) yang digunakan adalah lag dependen dan independen, dimana panjang lagi IV setiap model berbeda-beda untuk memperoleh hasil yang signifikan. Sampling untuk seluruh bank 110, big bank 17, medium banks 28, dan small bank 65, berdasarkan besarnya aset. Sampling periode dari Januari 2002 s.d November 2011 dengan menggunakan data bulanan longitudinal panel.

\begin{tabular}{|c|c|c|c|c|}
\hline \multicolumn{5}{|c|}{$\begin{array}{c}\text { Tabel } 4 \\
\text { Determinan likuiditas involuntary }\end{array}$} \\
\hline \multicolumn{5}{|c|}{ Dependent variable : Liquidity Involuntary $Y_{2 i, t}$} \\
\hline \multirow{2}{*}{ Variable } & All bank & Big bank & Medium bank & Small bank \\
\hline & (1) & (2) & (3) & (4) \\
\hline \multirow{2}{*}{$Y_{2 i, t-1}$} & 0,62 & 0,79 & 0,68 & 0,48 \\
\hline & $(102,32)^{*}$ & $(5,48)^{*}$ & $(32,2)^{*}$ & $(7,29)^{*}$ \\
\hline \multirow[t]{2}{*}{ BIRATE $_{t}$} & 0,09 & $-0,61$ & 0,19 & 0,08 \\
\hline & $(7,52)^{*}$ & $(-0,85)$ & $(2,65)^{*}$ & $(1,00)$ \\
\hline \multirow[t]{2}{*}{$\mathrm{ON}_{\mathrm{t}}$} & $-0,15$ & 0,51 & $-0,19$ & $-0,30$ \\
\hline & $(-15,93)^{*}$ & $(0,64)$ & $(-2,73)^{*}$ & $(-3,50)^{*}$ \\
\hline \multirow[t]{2}{*}{$\mathrm{ER}_{\mathrm{t}}$} & $-0,36$ & 0,17 & 0,29 & $-0,31$ \\
\hline & $(-15,19)^{*}$ & $(0,19)$ & $(1,92)^{* *}$ & $(-1,53)$ \\
\hline \multirow[t]{2}{*}{ CREDIT $_{i, t}$} & $-0,20$ & 0,14 & $-0,12$ & 0,10 \\
\hline & $(-6,77)^{*}$ & $(0,96)$ & $(-1,48)$ & $(0,73)$ \\
\hline \multirow[t]{2}{*}{$\mathrm{CAR}_{\mathrm{i}, \mathrm{t}}$} & 0,66 & 0,81 & 0,11 & 0,53 \\
\hline & $(38,69)^{*}$ & $(1,45)$ & $(1,8)^{\star \star \star}$ & $(2,15)^{\star \star}$ \\
\hline \multirow[t]{2}{*}{$\mathrm{FSI}_{\mathrm{t}}$} & $-0,15$ & $-0,05$ & $-0,07$ & $-0,08$ \\
\hline & $(-30,21)^{*}$ & $(-1,14)$ & $(-1,7)^{\star \star *}$ & $(-2,57)^{*}$ \\
\hline \multirow[t]{2}{*}{$\mathrm{GDP}_{\mathrm{t}}$} & 0,37 & 0,03 & 0,03 & 0,17 \\
\hline & $(29,71)^{*}$ & $(0,10)$ & $(0,52)$ & $(2,62)^{*}$ \\
\hline J Sargan test & 107,88 & 7,86 & 844,4 & 64,28 \\
\hline ( $p$ value) & 0,54 & 0,97 & 0,00 & 0,63 \\
\hline Number of Bank & 110 & 17 & 28 & 65 \\
\hline
\end{tabular}


276 Buletin Ekonomi Moneter dan Perbankan, Januari 2014

Halaman ini sengaja dikosongkan 